\title{
連想構造を持つリストにおける検索誘導性忘却への 加齢の影響
}

\author{
松田 崇志 松川 順子 金沢大学 \\ Aging and retrieval-induced forgetting of associatively structured lists \\ Takashi Matsuda and Junko Matsukawa (Kanazawa University)
}

Research on retrieval-induced forgetting has shown that remembering can cause forgetting of related information. This study examined whether such forgetting occurred for associatively structured lists and if aging influenced such forgetting. We compared retrieval-induced forgetting during a free recall test by using Deese/Roediger-McDermott (DRM) lists with an associative structure as the stimulus. Two age groups of young and old adult participants were tested. The results indicated that both age groups showed the same degree of retrieval-induced forgetting of the lists. These results suggest that the association between items causes retrieval-induced forgetting and that the inhibitory function of the association in retrieval-induced forgetting does not decline with age.

Key words: retrieval-induced forgetting, aging, associative relation.

The Japanese Journal of Psychology

2010, Vol. 81, No. 5, pp. 517-522

我々が記憶からある項目（ターゲット項目）を検索 すると, その検索行為により, 後のターゲット項目自 身の検索可能性は増加する。しかし，一方で，ターゲ ット項目と関連した項目は抑制され, 検索可能性が低 下する。この検索による関連項目の検索可能性の低下 は検索誘導性忘却（retrieval-induced forgetting）と呼 ばれる(Anderson, Bjork, \& Bjork, 1994)。検索誘導 性忘却研究の多くは検索経験パラダイム（retrievalpractice paradigm）と呼ばれる手続きを用いている。 検索経験パラダイムは, 典型的に, 学習段階, 検索経 験段階，テスト段階という三つの段階から構成され る。学習段階では, 実験参加者はカテゴリと事例の対 (例 : fruit-orange, fruit-banana, drink-scotch) を学 習する。検索経験段階では，学習リストの一部を手が かり再生テスト（例：fruit-or）により思い出す。テ スト段階では, カテゴリ名と事例の最初一文字を手が かりとして，全学習事例の再生を行う。その結果，検 索経験段階において，検索対象となったカテゴリに属 しており，かつ検索された事例（例：orange，以下

Correspondence concerning this article should be sent to: Takashi Matsuda, Graduate School of Human and Socio-Environment Studies, Kanazawa University, Kakuma-machi, Kanazawa, 920-1192, Japan (e-mail: matsudat@staff.kanazawa-u.ac.jp)
$\mathrm{Rp}$ 十項目とする）は, 検索対象とならなかったカテ ゴリに属する事例（例：scotch, 以下 Nrp 項目とす る）よりも再生成績が向上する。一方，検索経験段階 において，検索対象となったカテゴリに属するが，検 索されなかった事例（例：banana, 以下 Rp一項目と する）は Nrp 項目よりも再生成績が低下する。この 低下が検索誘導性忘却である。

この検索誘導性忘却は, ターゲット項目（実験手続 き上では， $\mathrm{Rp}$ +項目）を適切に検索するために, 夕 ーゲット項目と関連している項目（実験手続き上で は， Rp－項目）を抑制するという抑制機能（inhibitory function) によって生じると考えられている (Anderson \& Spellman, 1995)。Anderson \& Spellman （1995）によれば, ターゲット項目を検索する時, 夕 ーゲット項目と関連している項目も同時に活性化さ れ, ターゲット項目の検索と競合する。そこで, ター ゲット項目を適切に検索するには，この競合状態を解 決しなければならず，関連項目が抑制されることにな る。

上記のように, 検索誘導性忘却研究の多くは, 手が かりと学習項目を対呈示し, 手がかりにカテゴリ名 (例：fruit), 学習項目にカテゴリ事例 (例 : orange) を使用している。この方法では, 実験参加者にカテゴ リ情報が明示的に与えられることとなり（月元・川 
口，2005), 実験参加者は学習項目間の関係性を明確 にとらえることができると考えられる。つまり，学習 項目間にカテゴリ関係が形成されており, カテゴリ名 とカテゴリ事例の対呈示によって, その関係性が明示 されている場合, それらの項目間に抑制機能が働き, 検索誘導性忘却がみられるということが明らかであ る。

では，学習項目間の関係性が明示されていない場合 には検索誘導性忘却は生じるのだろうか。このような 学習項目の候補の一つとして, 虚記憶 (false memory) 研究で使用されてきた連想構造を持つ DRM リスト をあげることができる。DRM リストは, 学習段階で 呈示されない単語（例：sleep, 以下クリティカル語 とする) から連想される単語 (例 : bed, rest, awake, 以下リスト語とする) で構成されており, それらの項 目は連想的な関係性による連想ネットワーク構造を持 つとされている (Roediger \& McDermott, 1995)。し かし, DRM リストには学習項目 (リスト語) 間の関 係性を明示するような情報は含まれず，実験参加者に とって, リスト語間の関係性を明確にとらえることは 困難であると考えられる。つまり，DRM リストは， 学習項目間に関係性 (連想的な関係性) が形成されて いるが，その関係性が明示されていないという特徵を 持つ。多くの研究で使用されている刺激と比較する と, 学習項目間に関係性が形成されていることは共通 しているが，その関係性が明示されていないという点 で異なる。

Bäuml \& Kuhbandner（2003）は，DRM リストを 用いて, 検索誘導性忘却について検討している。 Bäuml \& Kuhbandner (2003) では, 手がかりとの対 呈示を行わず，DRM リストの項目のみを呈示した。 まず，実験参加者は DRM リストの項目を学習した。 この時クリティカル語は呈示されなかった（実験 2)。 その後, 検索経験として, 学習リストの一部を手がか り再生テストにより思い出した。最後に, 全学習項目 の自由再生を行った。その結果, リスト語とクリティ カル語の両方において, 検索誘導性忘却がみられた。 したがって, 学習項目間に連想的な関係性が形成され ていれば, その関係性が明示されていなくとも, 検索 時に関連（連想的な関係性にある）項目を抑制する機 能が働くことがわかった。このことから, 検索誘導性 忘却の生起に学習項目間の関係性の形成が重要である ことが示唆される。

このように, DRMリストを用いた Bäuml \& Kuhbandner（2003）では, 検索誘導性忘却がみられて いるが，このことは高齢者にも当てはまるだろうか。 これまで, 典型的なカテゴリと事例の対を用いて, 検 索誘導性忘却への加齢の影響を検討した研究はいくつ かある (Aslan, Bäuml, \& Pastötter, 2007; Moulin, Perfect, Conway, North, Jones, \& James, 2002)。それ
らの研究では, 高齢者群においても検索誘導性忘却が みられた。このことは, 検索時に関連項目を抑制する 機能が加齢によって減退しないことを示している。一 方で, Hasher \& Zacks（1988）は，ワーキングメモリ 課題において, 高齢者が不適切な情報を抑制する機能 が減退していると主張している。しかし，このことに ついて, Aslan et al. (2007) は高齢者の抑制機能の減 退が全般的なものではなく, 課題に依存していると主 張している。そのため, 加齢に伴い減退する抑制機能 と減退しない抑制機能があると考えられる。これらの ことから，少なくとも，カテゴリと事例が対呈示され た時（すなわち，学習項目間の関係性が明示されてい る時）は，高齢者においても，検索時に関連項目を抑 制する機能が働き, その抑制機能は加齢により減退し ないと言える。

しかし, 学習項目間の関係性が明示されていない場 合, 高齢者においても, 検索時に抑制機能が働くかど うか, またその抑制機能が加齢により減退しないかど うかについて, 現段階では不明である。そこで, 本研 究では, Bäuml \& Kuhbandner (2003) と同様に, 連 想構造を持つDRM リストを使用し, 学習項目間に 連想的な関係性が形成されているが，その関係性が明 示されていない場合における検索時の抑制機能につい て, 若年者と高齢者の比較検討していく。

本研究における高齢者群の結果を予測する手がかり として, DRMリストを使用した虚記憶に関する加齢 研究があげられる。Balota, Cortese, Duchek, Adams, Roediger, McDermott, \& Yerys (1999) や Norman \& Schacter（1997）では，DRM リストを使用した時， 高齢者においても虚記憶がみられるということが報告 されている。これらの結果は, DRM リストの項目に 関して, 若年者群と同様に, 高齢者群も連想ネットワ ーク構造を持っており, 項目間に関係性を形成してい ることを示している。検索誘導性忘却の生起におい て, 学習項目間の関係性の形成が重要であることが示 唆されている (Bäuml \& Kuhbandner, 2003)。そのた め, 若年者群と同様に, 項目間に関係性が形成されて いると考えられる高齢者群においても, リスト語とク リティカル語の両方において検索誘導性忘却がみられ ると予測される。一方, 若年者群については, Bäuml \& Kuhbandner (2003) から, リスト語とクリティカ ル語の両方において検索誘導性忘却がみられると予測 される。

本研究では, 若年者群と高齢者群の両方において, 検索誘導性忘却がみられると予測される。しかし, 検 索誘導性忘却の効果量が若年者群と高龃者群で異なる 可能性がある。そのため, 抑制機能への加齢の影響を より詳細に検討するために, 抑制効果量 (Nrp 項目 の再生成績-Rp－項目の再生成績）を分析の対象とす る。もし検索時に関連項目を抑制する機能が加齢に伴 
い減退しないのであれば，若年者群と高齢者群の抑制 効果量に差がみられないはずである。しかし，もし抑 制機能が加齢に伴い減退するのであれば，若年者群と 高齢者群の抑制効果量に差がみられるはずである。

\section{方法}

実験参加者 実験参加者は若年者（大学生）18 名 (男性 6 名, 女性 12 名, 平均年齢 21.3 歳, 標準偏差 1.0 歳, 平均教育歴 15.3 年, 標準偏差 1.0 年) と高齢 者 17 名（男性 11 名, 女性 6 名, 平均年齢 69.5 歳, 標準偏差 3.0 歳, 平均教育歴 12.5 年, 標準偏差 1.9 年) であった。高齢者は K 市シルバー人材センターに登 録している心身の健康な者であった。また，若年者と 高齢者ともに，実験終了後に，謝礼が支払われた。な お，健常であることを確認するために，高齢者に対し て事前に行った長谷川式簡易知能評価得点（HDSR）の平均得点は 27.8 点（標準偏差 2.0 点）であり, 高齢者群の実験参加者全員が自立判定の基準となる 21 点を上回っていた。

実験材料 使用した単語リストは宮地・山（2002） の日本語の DRM リストから虚再生率の高い6 リス トを選択した。使用したリストは“悪魔”, “希望”, “自殺”, “電波”, “平和”, “礼儀”をクリティカル語 としたリストであった。これらの 6 リストを検索経験 条件々計算課題条件に割り振るために, 三つのリスト を 1 セットとし，二つのリストセットを作った。この 時，宮地・山（2002）に扔いて報告されたリストセッ 卜の平均虚再生率が同等になるように，リストが割り 振られた。リストセット 1 は“悪魔”, “平和”, “礼 儀”, リストセット 2 は“希望”, “自殺”, “電波”で あった。

それぞれのリストはクリティカル語から連想される 15 項目から構成された（例：“悪魔”リストでは, 黒, サタン, 怖い, など)。リスト内の項目の呈示順 序は, 宮地・山（2002）が使用した呈示順序の通りと し, 常に一定であった。項目の表記は宮地・山 （2002）に従ったが，漢字が含まれている項目には, その上に読み方を示した。

検索経験段階に関して, 検索経験条件では, 検索経 験をさせるために, 単語穴埋め課題を行った。検索手 がかりとして各項目のフラグメント（例：“黒”に対 して，〈ロ）を使用した。それぞれのフラグメントに 対して回答候補が一つになるように, 手がかりを作成 した。 2 から 4 文字の項目の時は 1 文字, 5 文字以上 の時は 2 文字をフラグメント化した。項目に漢字が含 まれている時, ひらがなに変換した。検索経験の対象 となる項目は, それぞれの学習リストの奇数番目か偶 数番目に呈示された 7 項目を使用した。ただし, “自 殺”リストには “死”という 1 文字の単語があり, こ の項目は検索経験の対象から除かれた。
手続き 実験は若年者群では個別に行われたが，高 齢者群では，実験の都合上，3名から 5 名の集団で行 われた1。一つのリストに対して, 学習段階, 検索経 験段階，テスト段階を行った。これを 1 試行とし，全 てのリストに対して行ったため，実験は合計で 6 試行 行われた。1 試行の間には休憩はなく連続して行われ たが, 試行間には 5 分ほどの休覣を取った。

学習段階では，15 個のリスト語が一つずつ 2 秒間 呈示された。この時, クリティカル語は呈示されなか つた。実験参加者は後の記憶テストのために, それら の単語を記憶することが求められた。

次に, 検索経験段階に入った。検索経験条件では, 手がかりとして，フラグメントがランダムな順序で 4 秒間呈示された。実験参加者はそれらを見て, 対応す る学習段階で記憶した単語を思い出し, 書き出した。 検索経験条件において呈示されたリス卜語が Rp+項 目となり，呈示されなかったリス卜語が Rp－項目と なった。検索経験条件は 3 試行あった。計算課題条件 では，検索経験条件の項目数に対応する 7 個の計算課 題を行った。計算課題は 4 秒間呈示され, 実験参加者 はその間にその解答を書き出した。計算課題条件にお けるリスト語が Nrp 項目となった。計算課題条件は 3 試行あった。検索経験条件と計算課題条件は交互に 配置された。この時, 全てのリストが検索経験条件と 計算課題条件に平等に割り当てられ，かつそれぞれの リストが呈示順序の全ての位置にくるように, 試行順 序の組み合わせを六つ作り，実験参加者に割り当てた。

最後に，テスト段階において自由再生テストが実施 された。自由再生テストでは, 実験参加者は, 2 分の 間に，順序を問わず，学習段階で記憶した単語をでき るだけ多く思い出し, 書き出した。回答に際して, 実 験参加者には推測に頼らないよう教示した。

実験計画は，実験中に実際に呈示されたリスト語で は，年齢群 2 (若年者群・高齢者群) と項目のタイプ 3（検索経験条件のリスト語で検索経験を行った項 目：Rp+項目・検索経験条件のリスト語で検索経験 を行っていない項目：Rp一項目・計算課題条件のリ スト語：Nrp 項目）であった。年齢群は実験参加者 間要因であり, 項目のタイプは実験参加者内要因であ った。実験中には呈示されていないクリティカル語で は, 年齢群 2 (若年者群・高齢者群) と条件 2 (検索 経験条件・計算課題条件) であった。年齢群は実験参

1 若年者群では, 刺激はコンピュータディスプレイ上に呈示 された。高齢者群では, 刺激はプロジェクターからスクリーン に投影して呈示された。高齢者群については, 全ての実験参加 者が刺激を見やすい位置に座った。また, 他の実験参加者の存 在の影響を小さくするために, 実験参加者同土は適当な距離を とり, 座った。このことから, 実験を個別に行った場合と集団 で行った場合の違いによる結果への影響はほとんどないと考え られる。 
Table 1

それぞれの年齢群におけるリスト単語の平均再生率（\%）と標準偏差（括弧内）, クリティカル単語の平均虚再生率 (\%) と標準偏差（括弧内）

\begin{tabular}{|c|c|c|c|c|c|c|}
\hline & & $\mathrm{Rp}+$ & $\mathrm{Rp}-$ & Nrp & 促進効果 & 抑制効果 \\
\hline \multirow{3}{*}{ リスト単語 } & 若年者 & $88.4 \quad(8.0)$ & $64.8(11.2)$ & $70.4 \quad(6.9)$ & $18.0(10.2)$ & $5.6(9.7)$ \\
\hline & 高齢者 & $52.4(13.7)$ & $32.1(14.6)$ & $40.4(13.9)$ & 12.0 & $8.3(8.0)$ \\
\hline & & Rp リスト & Nrp リスト & & & \\
\hline \multirow{2}{*}{ クリティカル単語 } & 若年者 & $11.1(19.2)$ & $27.8(27.8)$ & & & \\
\hline & 高齢者 & $51.0(35.6)$ & $58.8(25.1)$ & & & \\
\hline
\end{tabular}

加者間要因であり, 条件は実験参加者内要因であっ た。

\section{結果}

検索経験 検索経験段階での検索対象項目 $(\mathrm{Rp}+$ 項目）の再生率は, 若年者群で $97.6 \%$, 高齢者群で 85.7\%であった。分散分析の結果, 若年者と高齢者の 再生率に有意な差があった $(F(1,33)=33.09, p<.001)$ 。

自由再生テスト リスト語とクリティカル語に対す るそれぞれの条件の再生率と虚再生率を算出し, その 結果を Table 1 に示した。リスト語の再生率に対して 年齢群 2(若年者群・高齢者群) $\times$ 項目のタイプ 3 $(\mathrm{Rp}+$ 項目 $\cdot \mathrm{Rp}$-項目 $\cdot \mathrm{Nrp}$ 項目 $)$ の分散分析を行 った。その結果, 年齢群の主効果 $(F(1,33)=96.26$, $p<.001)$, 項目の夕イプの主効果が有意であった $(F(2,66)=70.99, p<.001)$ 。項目のタイプの主効果 についてのライアン法による多重比較の結果, Rp+ 項目の再生率 $(70.4 \%)$ は Rp 一項目 $(48.5 \%)$ や Nrp 項目 $(55.4 \%)$ よりも有意に高かった。 $\mathrm{Rp}$ 一項目の 再生率は Nrp 項目よりも有意に低く（全て $p<.001 ）$, 検索誘導性忘却を示していた。

クリティカル語の虚再生率に対して年齢群 2（若年 者群・高齢者群) $\times$ 条件 2 (検索経験条件・計算課題 条件）の分散分析を行った。その結果, 年齢群の主効 果が有意であった $(F(1,33)=24.17, p<.001)$ 。また, 条件の主効果が有意であり $(F(1,33)=4.15, p<.05)$, 検索経験条件の虚再生率 $(31.0 \%)$ は計算課題条件 (43.3\%) よりも有意により低く, 検索誘導性忘却を示 した。年齢群と条件の交互作用は有意ではなかった。

検索誘導性忘却の促進効果と抑制効果の量を若年者 群と高齢者群で直接的に比較するために, リスト語に おけるそれぞれの年齢群の促進効果量 $(\mathrm{Rp}+$ 項目の 再生成績-Nrp 項目の再生成績) と抑制効果量（Nrp 項目の再生成績-Rp-項目の再生成績）を算出し, 個 別に年齢群間の $t$ 検定を行った。その結果, 促進効果 量は, 若年者群 $(18.0 \%)$ の方が高齢者群 $(12.0 \%)$ よりも有意に高い傾向があった $(t(33)=1.87, p<.10)$ 。 抑制効果量は, 若年者群 $(5.6 \%)$ と高齢者群 $(8.3 \%)$ の間に有意な差はなかった $(t(33)=0.88, n s)$ 。
最後に, 自由再生における $\mathrm{Rp}$ +項目と $\mathrm{Rp}$ 一項目 の再生の優先順序の傾向別に抑制効果量に対する分析 を行った。Macrae \& MacLeod（1999）の方法を採用 した。実験参加者ごとに $\mathrm{Rp}+$ 項目の平均再生位置と $\mathrm{Rp}$ 一項目の平均再生位置を算出し, $\mathrm{Rp}$ 一項目の值か ら $\mathrm{Rp}$ +項目の值を引き, 得点化した。それらの得点 の中央值を算出した。中央值より上の得点を取った実 験参加者を $\mathrm{Rp}+$ 項目を前半に再生した（Rp+項目優 先）群とし, 中央值より下の得点を取った実験参加者 を $\mathrm{Rp}$ 一項目を前半に再生した（ $\mathrm{Rp}$ 一項目優先）群と した。その結果, 若年者群の $\mathrm{Rp}+$ 項目優先群に 9 名, $\mathrm{Rp}$ 一項目優先群に 9 名, 高齢者群の $\mathrm{Rp}+$ 項目優 先群に 8 名, $\mathrm{Rp}$ 一項目優先群に 9 名が振り分けられ た。若年者の $\mathrm{Rp}$ +項目優先群の抑制効果量は $6.2 \%$ $(S D=11.6), \mathrm{Rp}$ 一項目優先群は $4.9 \% \quad(S D=7.2)$, 高 齢者では, それぞれ $10.8 \%(S D=10.2)$ と $6.0 \%$ $(S D=4.3)$ であった。これらに対して年齢群 2（若年 者群・高齢者群 $) \times$ 再生順序傾向 $2(\mathrm{Rp}+$ 項目優先 群・ Rp 一項目優先群) の分散分析を行った。その結 果, 有意な主効果および交互作用は認められなかっ た。

\section{考察}

本研究では, DRM リストを用いて, 学習項目間の 関係性が明示されていない時, 高齢者群においても, 検索時に抑制機能が㗢くかどうか，またその抑制機能 が加齢により減退するかどうかを検討することを目的 とした。その結果, リスト語では, 若年者群と高齢者 群の両方において, 検索誘導性忘却がみられた。ま た, その抑制効果量は若年者群と高齢者群で有意な差 がなかった。実際には呈示されなかったクリティカル 語では, 虚再生率は検索経験を行った検索経験条件の 方が計算課題を行った条件よりも有意により低く, 検 索誘導性忘却がみられた。

本研究のリス卜語の結果は, 学習項目間に連想的な 関係性が形成されているが，その関係性が明示されて いない時でも, 年齢にかかわらず, 検索時に抑制機能 が働き, ターゲット項目と連想的な関係性を持つ項目 が抑制されることを示している。連想的な関係性を持 
つ項目は，連想関係によって結びついており，連想ネ ットワーク構造を持っていると考えられる。そのよう な連想ネットワーク構造の中から特定のターゲット項 目を検索する時, ターゲット項目と連想的な関係性に ある項目も同時に活性化され，活性化資源を奪い合う こととなる。ターゲット項目を適切かつ迅速に検索す るため, この競合状態を解消するように抑制機能が働 く。その結果として，検索誘導性忘却がみられたと考 えられる。さらに, 抑制効果量を比較した結果, 若年 者群と高齢者群で有意な差はなかった。したがって, 検索時に連想的な関係性を持つ項目を抑制する機能も また加齢によって減退しないということが示された。

また, Aslan et al.（2007）は, カテゴリと事例を対 呈示した時（すなわち，学習項目間の関係性が明示さ れている時)，検索時に抑制機能が働き，その機能が 加齢に伴い減退しないということを示した。本研究の 結果と合わせて考えると，学習項目間に関係性が形成 されていれば，その関係性が明示されているかどうか にかかわらず，検索時に関連項目を抑制する機能が働 き, その抑制機能は加齢に伴い減退しないということ が示唆される。

様々な認知機能が加齢によって減退すると言われて いる（Birren \& Schaie, 2006 藤田・山本監訳 2008） 中で，なぜ検索時に関連項目を抑制する機能は加齢に よって減退しないのだろうか。考えられる一つの可能 性として，課題を遂行するために必要とされる処理の 違いが挙げられる。Hasher \& Zacks（1979）では，課 題を遂行するために必要とされる処理の自動性と意図 性の違いによって加齢の影響が異なり，意図的処理能 力は加齢に影響を受けやすく，自動的処理能力は加齢 の影響を受けにくいと考えられている。検索時に関連 項目を抑制する機能は自動的な処理であるとされてお り (Anderson, 2005)，そのために，加齢の影響を受 けにくいと考えられる。

本研究では，学習段階において呈示されていないク リティカル語についても検討した。その結果，クリテ イカル語についても, 若年者群と高齢者群の両方にお いて，検索誘導性忘却がみられた。クリティカル語 は, リスト語と同様の連想ネットワークに組み込まれ ており, リスト語の一部として学習されると考えられ ている (Roediger, Watson, McDermott, \& Gallo, 2001)。そのため，検索経験段階においてリスト語を 検索する時，連想ネットワーク上の活性化の拡散によ り, クリティカル語も活性化される。この活性化のた めに, クリティカル語もまたターゲット項目の検索と 競合することとなる。この競合を解決するために，ク リティカル語にも抑制機能が働き，検索誘導性忘却が みられたと考えられる。

また, クリティカル語の結果は, Bäuml \& Kuhbandner（2003）と同様であり，たとえ顕在的に
呈示されていなかったとしても，ターゲット項目と連 想的な関係性にある項目が抑制される可能性を示して いる。しかし，連想的な関係性にある項目の全てが抑 制の対象となるかは不明である。本研究で分析の対象 となったクリティカル語はターゲット項目からかなり 強く連想される項目であると言える。その連想の強度 が結果に影響しているかもしれない。今後, 連想強度 が検索誘導性忘却の生起に与える影響について検討す る必要がある。

本研究の検索経験段階では, 若年者群と高齢者群の 成績に有意な差がみられた。この成績の差は自由再生 テストの結果に影響しているかもしれない。しかし,

Storm, Bjork, Bjork, \& Nestojko（2006）は，検索誘導 性忘却の生起に検索経験段階の成績が影響しないとい うことを示した。また，本研究の高齢者群の検索経験 段階の成績は $85.7 \%$ と高く，検索経験として十分働 いていたと考えられる。これらのことから，検索経験 段階における成績の差が後の自由再生テストの結果に 影響している可能性は低いと考えられる。

本研究は, テストとして, 自由再生を用いており, 再生順序が統制されていない。そのため, 観察された 抑制効果が出力干渉 (output interference) によるも のである可能性がある。出力干渉とは, テスト時に最 初に再生された項目が関連した項目の検索に干渉する 現象である（Roedeiger \& Schmidet, 1980)。検索経験 を受けた Rp+項目は $\mathrm{Rp}$ 一項目よりも先に再生され やすく, Rp-項目は出力干渉の影響を受け, 再生率 が低下する可能性がある。この点を検討するために, $\mathrm{Rp}+$ 項目と $\mathrm{Rp}$ 一項目の再生順序の傾向別に抑制効果 量に対する分析を行った。その結果, Rp+項目優先 群と $\mathrm{Rp}$ 一項目優先群の抑制効果量に有意な差がある という証拠は得られなかった。この結果は出力順序に より抑制効果量に差がないということを示し, 本研究 においてみられた抑制効果が出力干渉によるものでは ないことを保証している。

まとめると, 学習項目間に連想的な関係性が形成さ れているが，その関係性が明示されていない場合で も, 若年者群と高齢者群の両方において検索誘導性忘 却が生じた。このことから, 項目間に何らかの関係性 を形成していることが検索誘導性忘却の生起に重要で あることが示唆される。さらに, 学習項目間に関係性 が形成されていれば，その関係性が明示されているか どうかにかかわらず，検索時に関連項目を抑制する機 能が㗢き,この抑制機能は加齢により減退しないとい うことが示された。

\section{引用文献}

Anderson, M.C. (2005) . The role of inhibitory control in forgetting unwanted memories: A consideration 
of three methods. In C. MacLeod \& B. Uttl (Eds.), Dynamic cognitive processes. Tokyo: SpringerVerlag. pp. 159-190.

Anderson, M.C., Bjork, R.A., \& Bjork, E.L. (1994) . Remembering can cause forgetting: Retrieval dynamics in long-term memory. Journal of Experimental Psychology: Learning, Memory, and Cognition, 20, 1063-1087.

Anderson, M.C., \& Spellman, B.A. (1995) . On the status of inhibitory mechanisms in cognition: Memory retrieval as a model case. Psychological Review, 102, 68-100.

Aslan, A., Bäuml, K.H., \& Pastötter, B. (2007) . No inhibitory deficit in older adults' episodic memory. Psychological Science, 18, 72-78.

Balota, D.A, Cortese, M.J., Duchek, J.M., Adams, D., Roediger, H.L. III, McDermott, K.B., \& Yerys, B.E. (1999). Veridical and false memories in healthy older adults and in dementia of Alzheimer's type. Cognitive Neuropsychology, 16, 361-384.

Bäuml, K.H., \& Kuhbandner, C. (2003) . Rtrievalinduced forgetting and part-list cuing in associatively structured lists. Memory \& Cognition, 31, 1188-1197.

Birren, J.E., \& Schaie, K.W. (2006). Handbook of the psychology of aging. 6th ed. San Diego, CA: Elsevier.

(ビリン J.E.・シャイエ K.W. 藤田 綾子・山本 浩市（監訳）(2008). エイジング心理学ハンドブ ック 北大路書房)

Hasher, L., \& Zacks, R.T. (1979) . Automatic and effortful processes in memory. Journal of Experimental Psychology: General, 108, 356-388.

Hasher, L., \& Zacks, R.T. (1988). Working memory, comprehension and aging: A review and new view. Psychology of Learning and Motivation, 22, 193225.

Macrae, C.N., \& MacLeod, M.D. (1999) . On recollections lost: When practice makes imperfect. Journal of Personality and Social Psychology, 77, 463-473.

宮地 弥生・山 祐嗣 (2002), 高い確率で虚記憶を生
成する DRM パラダイムのための日本語リスト の作成 基礎心理学研究， 21，21-26.

(Miyaji, Y., \& Yama, H. (2002) . Making Japanese lists which induce false memory at high probability for the DRM paradigm. Japanese Journal of Psychonomic Science, 21, 21-26.)

Moulin, C.A., Perfect, T.J., Conway, M.A., North, A.S., Jones, R.W., \& James, N. (2002). Retrievalinduced forgetting in Alzheimer's disease. Neuropsychologia, 40, 862-867.

Norman, K.A., \& Schacter, D.L. (1997) . False recognition in younger and older adults: Exploring the characteristics of illusory memories. Memory \& Cognition, 25, 838-848.

Roediger, H.L., III, \& McDermott, K.B. (1995). Creating false memories: Remembering words not presented in lists. Journal of Experimental Psychology: Learning, Memory, and Cognition, 21, 804-814.

Roediger, H.L., III, \& Schmidt, S.R. (1980). Output interference in the recall of categorized and pairedassociate lists. Journal of Experimental Psychology: Human Learning and Memory, 6, 91-105.

Roediger, H.L. III, Watson, J.M., McDermott, K.B., \& Gallo, D.A. (2001). Factors that determine false recall: A multiple regression analysis. Psychonomic Bulletin \& Review, 8, 385-407.

Storm, B.C., Bjork, E.L., Bjork, R.A., \& Nestojko, J.F. (2006). Is retrieval success a necessary condition for retrieval-induced forgetting? Psychonomic Bulletin \& Review, 13, 1023-1027.

月元 敬・川口 潤 (2005). カテゴリ競合とエピソー ド競合の影響——検索誘導性忘却の生起要因に関 する検討—— 認知心理学研究, 2, 63-71.

(Tsukimoto, T., \& Kawaguchi, J. (2005) . The cooccurrence of category-based and episode-based competitions as a general boundary condition on retrieval-induced forgetting. Japanese Journal of Cognitive Psychology, 2, 63-71.) 